\title{
Linking Islamic Work Ethic to Computer Use Ethics, Job Satisfaction and Organisational Commitment in Malaysia
}

\author{
Norshidah Mohamed, Nor Shahriza Abdul Karim and Ramlah Hussein \\ International Islamic University Malaysia
}

\begin{abstract}
This research seeks to investigate whether Islamic work ethic is linked to individuals' attitudes towards computer use ethics, job satisfaction and organisational commitment. The research used a cross-sectional self-administered survey method in the International Islamic University Malaysia. A total of 310 survey questionnaires were distributed to academic staff in four faculties i.e. Engineering, Information and Communication Technology, Human Science and Islamic Revealed Knowledge and Economics and Management Sciences faculties. Cluster sampling was used in the selection of academic staff from several randomly chosen class schedules. The study found that Islamic work ethic within a university environment is linked to individuals' attitudes towards computer use ethics, job satisfaction and organisational commitment. Implications and areas for future research are also discussed.
\end{abstract}

\section{Keywords}

Islamic work ethic, computer use ethics, job satisfaction, organisational commitment

\section{Introduction}

An individual's work ethic is an important facet in employment. It has been reported that a work ethic commanded higher priority than skills in hiring among employers since the early 1990s (Flynn, 1994). According to Beekun (1996), work ethic in its most basic form refers to the internalised view of work as the natural expression and stewardship of one's abilities and energies.

Islamic work ethic is based on the principles and teachings of Islam. Islam is supposed to be a complete way of life (Al-A'ali, 2008). For Muslims, the sources for Islamic principles and teachings

Copyright (C) 2010 Victoria University. This document has been published as part of the Journal of Business Systems, Governance and Ethics in both online and print formats. Educational and non-profit institutions are granted a nonexclusive licence to utilise this document in whole or in part for personal or classroom use without fee, provided that correct attribution and citation are made and this copyright statement is reproduced. Any other usage is prohibited without the express permission of the publisher. are the Qur'an and Hadith. The Qur'an contains verbatim words of Allah or God revealed to Prophet Muhammad (Peace be upon him) while the Hadith has words, actions and approvals of Prophet Muhammad (Peace be upon him).

The work ethic in Islam constitutes the expectations of one's relations with respect 
to his behaviour at work. This includes his or her effort, dedication, cooperation, responsibility, social relations and creativity (Rahman et al. 2006). Essentially, with a close relationship with God, one could expect to spur his attitudes and behaviour to be consistent with the rules and stipulations of the religion (Rahman et al. 2006). Islamic work ethic advocates the importance of performing one's work to the best of ability for the pleasure of God. As reported in Kheder (2001), "Allah likes it if one performs a task, he has to perform it perfectly". Kheder (2001) highlighted that when Muslim professionals were confronted with the dilemma between public and personal interests, they should give a priority in their behaviour to the interests of the public.

The last two decades saw the emergence of and continued scholarly discussions on Islamic work ethic in global and cross-cultural environment. Ali (1988) constructed the Islamic work ethic scale and found that the scale reliable when he tested it out among 150 Arab students in major universities in the United States. Since then, researchers used this scale in organisational and management context (Yousef, 2000; 2001; Rahman et al. 2006; Ali and Al-Kazemi, 2007; Khalil and Abu-Saad, 2009; Kumar and Rose, 2010). Yousef (2000) studied Islamic work ethic and attitudes towards organisational change and organisational commitment among employees in the United Arab Emirates. He found that employees' Islamic work ethic directly and positively influenced their attitudes towards organisational change and organisational commitment. Yousef (2001) investigated the moderating impact of Islamic work ethic on the relationships between organisational commitment and job satisfaction among 425 Muslim employees in several organisations in the United Arab Emirates. He found that Islamic work ethic directly affected both organisational commitment and job satisfaction. In a case study, Rahman et al. (2006) studied and found a relationship between Islamic work ethic and organisational commitment among 227 employees in a local bank in Malaysia.

In Kuwait, Ali and Al-Kazemi (2007) investigated the relationship between Islamic work ethic and loyalty and found a significant and strong relationship. Based on a review of literature, Ali and AlOwaihan (2008) suggested that Islamic work ethic contributed to higher performance, widespread prosperity and societal welfare.

Using in-depth interviews with 32 business people, Uygur (2009) studied Islamic work ethic in the context of Turkish small and medium-sized enterprises. However, he found that it was not a significant factor for their attitudes. Muhammad et al. (2008) provided a discussion of Islamic work ethic in Malaysian small and medium enterprises but did not test the scale. Khalil and Abu-Saad (2009) investigated the relationship between Islamic work ethic and individualism among Arab college students in Israel. They found that there was a significant correlation between Islamic work ethic and individualism scales. The findings of their study were consistent with that in Ali (1992) in Arabia. Kumar and Rose (2010) investigated the influence of Islamic work ethic on innovation capability in the Malaysian public sector. They found support for the relationship.

While there have been recent debates on Islamic work ethic as evident from the literature, it appears that the study of Islamic work ethic continues to be sparse. At the same time, it is recognised that in creating a competitive advantage and moving towards knowledge society, organisations make huge investments in technologies to equip their professionals. It is noted that prior studies in Islamic work ethic have not considered its link to technological use in organisations. Against this backdrop, we built upon the prior works of Ali (1988), Yousef $(2000 ; 2001)$ and Rahman et al. (2006) to gain insights into Islamic work ethic's link to individuals' computer use ethics, job satisfaction and organisational commitment.

\section{Attitudes towards Computer Use Ethics}

In organisations, professionals' awareness and organisational policies of ethical use of technologies often lag behind their rapid advancement. Hence, professionals at workplace may often be confronted with ethical dilemmas associated with technology that were perhaps not present a few decades ago. Based on a search result on articles published in journals, there appears to be a scant number on attitudes about ethical computer use and Islam. Al-A'ali (2008) concurred that "the relationship between information technology ethics and Islam has received very little or no attention". Some researchers who had attempted to study ethical computer use tended to conclude that personal 
religiousness, individuals' uncertainty, personal values and moral judgments influenced ethical behaviour in lieu of the lack of corporate code of ethics (Clark and Dawson, 1996; Pierce and Henry, 2000; Kreie and Cronan, 2000; Leonard and Cronan, 2005). Clark and Dawson (1996) highlighted the importance of religiousness as an influence of ethical judgments. Pierce and Henry (2000) suggested that some unethical acts were the result of an individual's uncertainty or misunderstanding of appropriate behaviour; that was perhaps attributable to a lack of proper guidance in decision-making. Kreie and Cronan (2000) concluded that personal values contributed to deciding whether a behaviour was ethical and unethical. Leonard and Cronan (2005) summed up that a person's moral judgment could help in ethical decision-making. Therefore, we hypothesise that:

H1: There is a significant and negative relationship between Islamic work ethic and attitude towards unethical computer use.

\section{Job Satisfaction}

Ensuring employees' retention in organisation is important. Employees are organisational assets and resources essential in achieving organisations' targets. An employee who is satisfied with his job may remain in the organisation. Likewise, an employee who is dissatisfied may have intention to leave the organisation. Human resource executives in corporate organisations should place a great importance in ensuring employees job satisfaction because losing staffs can be costly. When a staff leaves an organisation, organisations need to spend resources to recruit, hire and train new staff. Ivancevich et al. (1997) defined job satisfaction as an attitude that individuals have about their jobs. Studies on work ethic and job satisfaction seem sparse. In the United States, Elkins (2007) found that there was a weak correlation between work ethic and job satisfaction in a Japanese manufacturing company. In a study at a private Midwestern correctional organisation, Lambert and Hogan (2009) found that work ethic had the largest impact on job satisfaction. Hence, we hypothesise that:

H2: Islamic work ethic is significantly and positively related to job satisfaction.

H3: There is a significant and negative relationship between attitude towards unethical computer use and job satisfaction.

\section{Organisational Commitment}

Many past researches had a focus on employees' organisational commitment. This is important in that organisational commitment is a reliable predictor of certain behaviour (Yusuf and Shamsuri, 2006). According to Awamleh (1996), organisational commitment has gained prominence in management discourse since it plays an essential role in goal achievement, innovation and stability of an organisation. Mowday et al. (1979) defined commitment as the relative strength of an individual's identification with and involvement in a particular organisation. The findings for the link between job satisfaction and organisational commitment are mixed. For instance, Curry et al. (1986) found no support for the link between job satisfaction and organisational commitment. Peterson et al. (2003) did not find evidence for the link. Alpander (1990) found a strong positive correlation between job satisfaction and organisational commitment. In Greek organisations, Markovits et al. (2007) found support for the link between affective organisational commitment and intrinsic and extrinsic job satisfaction. Therefore, it is hypothesised that:

H4: Islamic work ethic is significantly and positively related to organisational commitment.

H5: There is a significant and negative relationship between attitude towards unethical computer use and organisational commitment.

H6: Job satisfaction is significantly and positively related to organisational commitment.

Hence, we set out the objectives of the research as follows: (1) To develop and test a theoretical research model (2) To investigate whether Islamic work ethic is linked to individuals' attitudes towards computer use ethics, job satisfaction and organisational commitment in an Islamic environment. Figure 1 shows the theoretical research model for this study. 


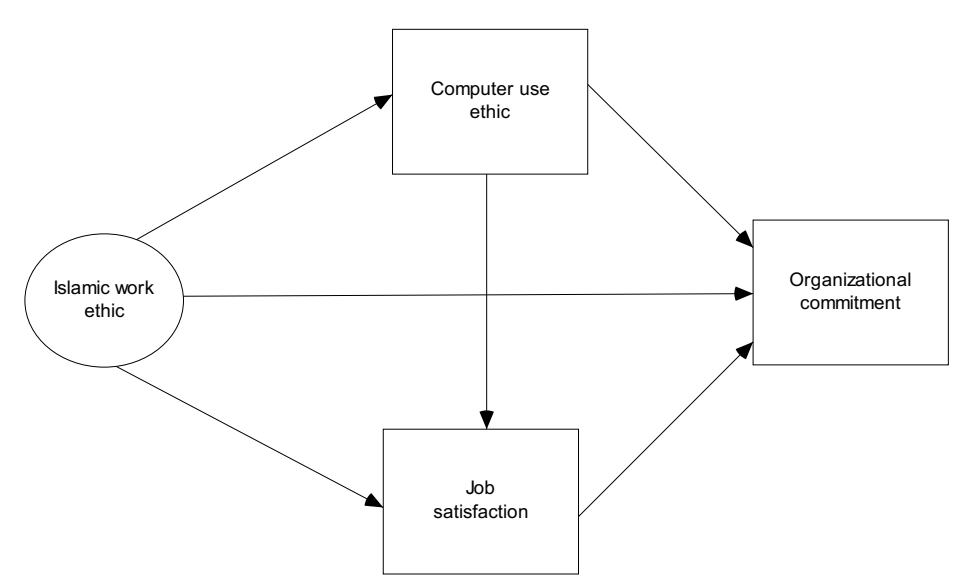

Figure 1: Research Model

\section{Research Design}

\section{Context of Study}

The International Islamic University Malaysia was selected as the context of study in that it integrates Islamic values as a main thrust in teaching and research. The university was established in 1983. It uses English as the medium of instruction. Its vision is "To be an international centre of educational excellence which integrates Islamic revealed knowledge and values in all disciplines and which aspires to the restoration of the Ummah's (Islamic society) leading role in all branches of knowledge." The University operates under the direction of a Board of Governors with representatives from eight sponsoring governments and the Organisation of Islamic Conference (OIC). It maintains links with governments and institutions all over the world, such as the League of Islamic Universities, the International Association of Universities and the Association of Commonwealth Universities. It is also affiliated with several Malaysian-based businesses that provide opportunities for students to gain practical work experience. The student population is nearing 30,000. There are about 1,600 academic staff; $60 \%$ of whom have a doctoral degree. The University has fields of study in sciences, engineering, law, information technology etc.

\section{Data Collection Method, Population and Sample}

In achieving the research objectives, the research used a cross-sectional self-administered survey method on the academic staff in the International Islamic University Malaysia. A total of 310 questionnaires was distributed to the academic staff. Four academic faculties namely Engineering, Information and Communication Technology, Human Science and Islamic Revealed Knowledge and Economics and Management Sciences were selected as the study's population. Cluster sampling was used in selecting academic staff from several randomly chosen class schedules.

\section{Instrument}

There were five sections in the questionnaire. Section one contained questions to probe respondents' values for Islamic work ethic. This is relevant and consistent with Al-A'ali (2008) in that all participants were Muslims. There were eight statements (a shorter version) adopted from Ali (1988) as measures for individual value for work ethic. Respondents were required to evaluate agreement to statements about work ethics that used a seven-point Likert scale. A seven-point represented strongly agree while a one-point represented strongly disagree to statements provided. Section two provided nine computer-related behaviour scenarios that were used to elicit respondents' attitudes towards responsible use, responsibility, acknowledgement, software piracy, unauthorised use of software, handling a disruptive behaviour, use of company's asset for personal and non-profit purpose, access to information for personal gain or profit, access to others' information for employer's or company's profit. 
This approach has been used in other and previous computer ethics studies. Measures were adopted from Paradice (1990) and Pierce and Henry (2000). Respondents were requested to first read each scenario and judged whether they agreed with what the action that the person in the scenario adopted. Each response was to be evaluated on a seven-point Likert scale. A seven-point represented strongly agree (ethical) while a one-point represented strongly disagree (unethical) with the action taken. Section three contained questions about staff's job satisfaction. Three questions were adapted from Minnesota satisfaction questionnaire and Michigan Organisational Assessment Questionnaire satisfaction. Respondents were required to evaluate agreement to statements about job satisfaction that used a seven-point Likert scale. A seven-point represented strongly agree while a one-point represented strongly disagree. In section four, there were nine questions about organisational commitment adapted from Porter et al. (1974) Organisational Commitment Questionnaire (OCQ). The questions have demonstrated good psychometric properties and are used in a wide range of job categories (Mowday et al. 1979). Respondents were required to evaluate agreement to statements about organisational commitment that used a seven-point Likert scale. A seven-point represented strongly agree while a one-point represented strongly disagree to statements provided. The last section sought to identify the respondents' characteristics including gender, age, ethnicity and length of work experience.

\section{Findings}

We received 150 questionnaires. However, only 143 were usable for analysis. The remainder had more than $80 \%$ of total questions unanswered and were, therefore, discarded from further analysis. The overall response rate was $47.2 \%$. Table 1 shows the breakdown of response rate for each faculty. We used SPSS Version 16 to generate descriptive statistics.

\begin{tabular}{|c|c|c|c|}
\hline \multirow[t]{2}{*}{ Faculty } & \multicolumn{2}{|c|}{ Frequency } & \multirow{2}{*}{$\begin{array}{c}\text { Response rate } \\
(\%)\end{array}$} \\
\hline & Distributed & Usable/Unusable & \\
\hline Engineering & 110 & $48 / 1$ & 44 \\
\hline $\begin{array}{l}\text { Information and Communication } \\
\text { Technology }\end{array}$ & 30 & $24 / 1$ & 82.7 \\
\hline $\begin{array}{l}\text { Human Science and Islamic } \\
\text { Revealed Knowledge }\end{array}$ & 110 & $40 / 3$ & 37.4 \\
\hline $\begin{array}{l}\text { Economics and Management } \\
\text { Sciences }\end{array}$ & 60 & $31 / 2$ & 53.4 \\
\hline Total & 310 & $143 / 7$ & 47.2 \\
\hline
\end{tabular}

Table 1: Breakdown of responses

Of the total respondents, $57 \%$ of them were male. About $17 \%$ of them claimed that they were below 29 years old. $39 \%$ of the total respondents were between 30 and 39 years old while the majority of them $(44 \%)$ were above 40 years old. A large proportion of respondents were Malaysian citizens (76\%) while the remainder are of other citizenship like Arab and African continent. All the respondents were Muslims. The range for the number of work experiences is 0 and 30 . The average number of work experiences reported were nine years.

Structural Equation Modelling technique was applied to detect the relationships amongst constructs. Consistent with Byrne (2001), we analysed each measurement model for respective construct defined earlier prior to analysing the structural model. Convergent validity is established if the loadings of the measures to their respective constructs are at least 0.60 (Bagozzi and Yi, 1988). Those not meeting this criterion were dropped from further analyses. We used AMOS Version 16 to generate measurement and structural models. 


\section{Reliability and Internal Consistency Check}

Based on the measurement model, we conducted the reliability test using SPSS Version 16. Table 2 shows the Cronbach's coefficient used to assess the reliability of all multi-item scales based on the result of the measurement model. All scales show reasonable reliability ranging from .781 to .921 . They were well above Kline (2005) generally adequate alpha level 0.70 indicating good scales.

\begin{tabular}{|l|r|}
\hline \multicolumn{1}{|c|}{ Factors } & \multicolumn{1}{c|}{$\alpha$} \\
\hline Islamic work ethic (5 items) & .880 \\
\hline Attitudes towards computer use ethics (5 items) & .871 \\
\hline Job satisfaction (3 items) & .781 \\
\hline Organisational commitment (8 items) & .921 \\
\hline
\end{tabular}

Table 2: Cronbach's coefficient for constructs

\section{Support for Hypotheses}

Hypothesis 1 proposed that there is a significant and negative relationship between professionals' values for Islamic work ethic and attitude towards unethical computer use. Professionals with higher regards for values in Islamic work ethic predicted negative attitudes towards unethical computer use $(\beta=-.37 ; p<.01)$. Likewise, professionals with lower regards for values in Islamic work ethic predicted acceptance for unethical use of the computers. Hypothesis 2 proposed that there is a significant and positive relationship between professionals' values for Islamic work ethic and job satisfaction. Professionals with higher regards for values in Islamic work ethic predicted higher job satisfaction $(\beta=.53 ; \mathrm{p}<.01)$. Similarly, professionals with lower regards for values for Islamic work ethic predicted lower job satisfaction. Hypothesis 3 suggested that there is a significant and negative relationship between attitude towards unethical computer use and job satisfaction. Professionals with negative attitudes towards unethical computer use predicted higher job satisfaction $(\beta=-.30 ; p<.01)$. Likewise, professionals who accepted unethical computer use had lower job satisfaction. Hypothesis 4 suggested that there is a significant and positive relationship between professionals' values for Islamic work ethic and organisational commitment. We found support for the hypothesised relationship $(\beta=.29$; $\mathrm{p}<.05$ ). Hypothesis 5 proposed for a significant and negative relationship between attitude towards unethical computer use and organisational commitment. We did not find support for the hypothesised relationship $(\beta=-.11 ; p>.05)$. Hypothesis 6 proposed for a significant and positive relationship between job satisfaction and organisational commitment. Professionals with higher job satisfaction exhibited higher commitment to the organisation $(\beta=.33 ; \mathrm{p}<.01)$. Likewise, professionals with lower job satisfaction exhibited lower commitment to the organisation. Table 3 summarises the results of the hypotheses.

\begin{tabular}{|l|c|}
\hline \multicolumn{1}{|c|}{ Hypotheses } & Findings \\
\hline H1: Islamic work ethic and computer use & Supported \\
\hline H2: Islamic work ethic and job satisfaction & Supported \\
\hline H3: Computer use and job satisfaction & Supported \\
\hline $\begin{array}{l}\text { H4: Islamic work ethic and organisational } \\
\text { commitment }\end{array}$ & Supported \\
\hline H5: Computer use and organisational commitment & Not supported \\
\hline H6: Job satisfaction and organisational commitment & Supported \\
\hline
\end{tabular}

Table 3: Summary of Hypotheses Results 


\section{Evaluation of Structural Model}

The confirmation of the overall proposed model was important in providing empirical evidence on the impact of Islamic work ethic (see Figure 2 and Table 4). 13\% of the variation in computer use ethic can be explained by professionals' values for Islamic work ethic. $49 \%$ of the variation in professionals' job satisfaction can be explained by professionals' values for Islamic work ethic and attitudes towards computer use ethic.

In comparison, Islamic work ethic had a higher contribution than attitude towards computer use on job satisfaction. $39 \%$ of the variation in organisational commitment can be explained by professionals' job satisfaction. We reviewed the goodness for fit measures. The $\chi^{2}=24.73 ; \mathrm{df}=17 ; \mathrm{p}=.101$. Following the guideline given in Raykov (2000), the model showed excellent approximation of the data. The RMSEA $=.057$ which is approaching .05 indicates reasonable error of approximation and close to fitting the model that explained the impact of Islamic work ethic on professionals' attitudes towards computer use, job satisfaction and organisational commitment. Overall, the findings indicated that the fit for the structural model was excellent.

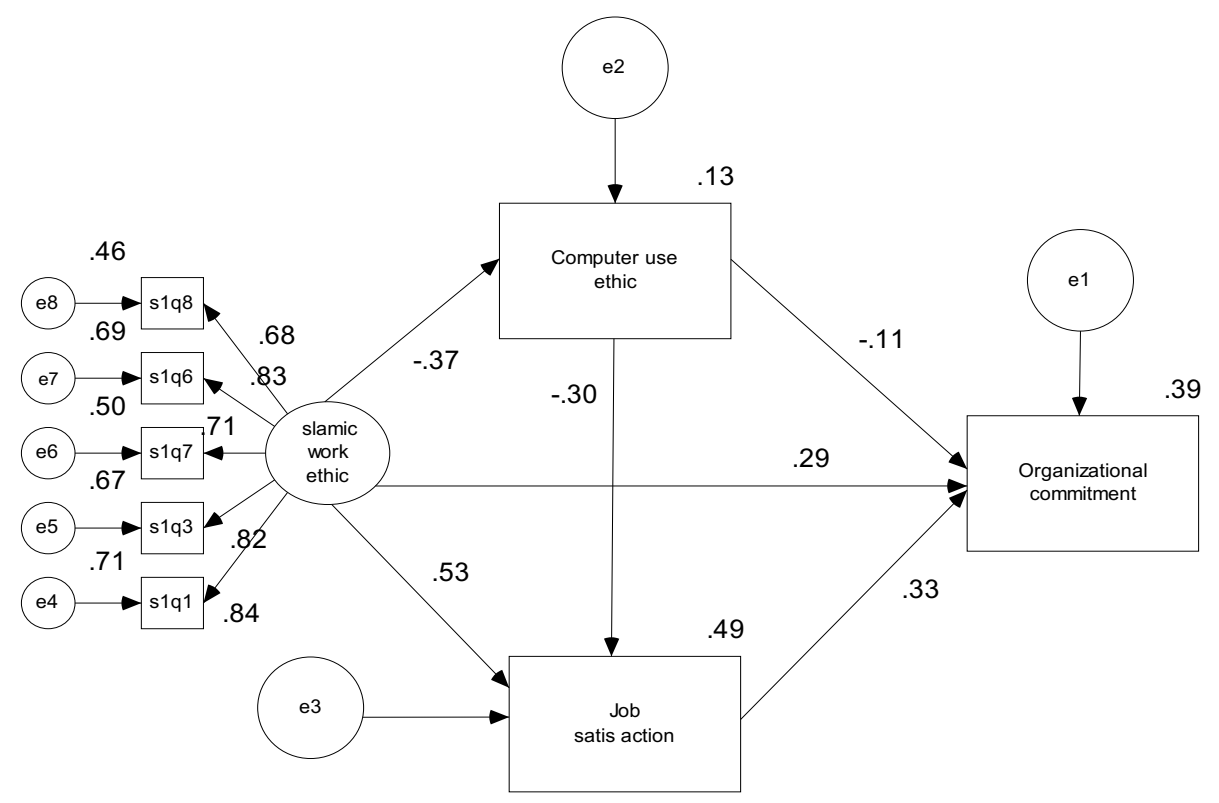

Figure 2: Structural Model

\begin{tabular}{|l|l|l|}
\hline \multicolumn{1}{|c|}{ Fit measure } & Recommended value & \multicolumn{1}{|c|}{$\begin{array}{c}\text { Value for the } \\
\text { research model }\end{array}$} \\
\cline { 1 - 1 }$\chi^{2}$ & & 24.73 \\
\cline { 1 - 1 } Degrees of freedom (df) & & 17 \\
\hline$\chi^{2} /$ df & $<3$ & 1.45 \\
\hline p-value & $>.05$ & .101 \\
\hline GFI & $>.90$ & .958 \\
\hline Adjusted GFI & $>.90$ & .911 \\
\hline Normed fit index (NFI) & $>.90$ & .956 \\
\hline Relative fit index (RFI) & $>.90$ & .928 \\
\hline Incremental fit index (IFI) & $>.90$ & .986 \\
\hline Tucker Lewis index (TLI) & $>.90$ & .976 \\
\hline Comparative fit index (CFI) & $>.90$ & .986 \\
\hline $\begin{array}{l}\text { Root mean square error of } \\
\text { approximation (RMSEA) }\end{array}$ & $<.08$ & .057 \\
\hline Root mean square residual (RMR) & $<.08$ & .037 \\
\hline
\end{tabular}

Table 4: Goodness of fit measures 


\section{Conclusion}

Islamic work ethic began to receive attention in the late 80 's. Since then, it has not been a widely explored area. Many gaps still exist. The purpose of this study was to investigate its link to individuals' computer use ethics, job satisfaction and organisational commitment. The findings suggest that Islamic work ethic influenced individuals' attitudes towards computer use ethic. These are important characteristics that guide an individual's view on ethical use of computer when faced with a dilemma. The fact that there were significant contributions of Islamic work ethic and attitudes towards computer use ethic to job satisfaction suggest that individuals' ethics are an important consideration towards managing a satisfied workforce. It is interesting to note that computer use ethic had no significant and direct influence on organisational commitment. Another important finding is that, professionals' Islamic work ethic and job satisfaction positively, directly and significantly relate to organisational commitment.

Professionals' Islamic work ethic positively, indirectly and significantly relate to organisational commitment. This suggests that those who value Islamic ethic are satisfied in their jobs and thus tend to put a higher commitment in work. The research has rendered two practical implications to employers. Employers should continue emphasising on the importance of ethics when recruiting professionals. Employers should focus on employees' life-long learning, curriculum development for professionals and inculcating appropriate individual work values in the use of computers.

Employers should consider continuous training, communication and consistent behaviour that adhere to corporate code of ethics. Development program contents may encompass Islamic work ethic, computer ethics and security awareness programs. Another possibility is to make aware to employees of in-house policy, the importance of Islamic work ethic and ethical use of computers in the workplace.

This research acknowledges three limitations. Firstly, the sample was selected from a university in Malaysia and in particular an Islamic university. Furthermore, all respondents were Muslims. This limits comparisons between Muslims and non-Muslims and restricts generalisation to other universities or corporate bodies. Secondly, the sample size was only 143. Thirdly, only those in the category of professionals (knowledge worker) were involved. With a larger sample size, we would have been able to conduct a comparison on different professionals' characteristics such as respondents' religious background, age, and positions. Future studies should use a larger sample to enable comparisons and look at the perspectives of non-Muslims, other universities and corporate bodies and support staff.

\section{Acknowledgement}

The research is supported by the International Islamic University Malaysia. The authors thank the anonymous reviewers for their helpful comments and suggestions.

\section{References}

Al-A'ali, M 2008, "Computer ethics for the computer professionals from an Islamic point of view", Journal of Information, Communication \& Ethics in Society, vol. 6, no. 1, pp. 28-45.

Ali, A 1988, "Scaling and Islamic Work Ethic", The Journal of Social Psychology, vol. 128, no. 5, pp. $575-83$.

Ali, A 1992, "Islamic work ethic in Arabia", Journal of Psychology, vol. 126, no. 5, pp. 575-583.

Ali, A \& Al-Kazemi, A 2007, "Islamic work ethic in Kuwait", Journal of Management Development, vol. 14, no. 2, pp. 366-75.

Ali, A J \& Al-Owaihan, A 2008, "Islamic work ethic: a critical review", Cross Cultural Management Development, vol. 14, no. 6, pp. 5-19.

Alpander, G G 1990, "Relationship between commitment to hospital goals and job satisfaction: a case study of a nursing department", Health Care Management Review, vol. 15, no. 4, pp. 51-62.

Awamleh, N A 1996,"Organisational commitment of civil service managers in Jordan: a field study", Journal of Management Development, vol. 15, pp. 65-74. 
Bagozzi, R P \& Yi, Y 1988, "On the evaluation of structural equation models", Journal of the Academy of Marketing Science, vol. 16, no. 1, pp. 74-94.

Beekun, R 1996, Islamic Business Ethics, viewed 20 February 2006, http://www.islamist.org/images/ethicshm.pdf

Beekun, R I \& Badawi, J A 2005, "Balancing ethical responsibility among multiple organisational stakeholders: the Islamic perspective", Journal of Business Ethics, vol. 60, pp. 131-145.

Byrne, B 2001, Structural Equation Modeling with AMOS. Philadelphia, Lawrence Erlbaum.

Clark, J W and Dawson, L E 1996, "Personal religiousness and ethical judgements: An empirical analysis." Journal of Business Ethics, vol. 15, no. 3, pp. 359-372.

Curry, J, Wakefield, D, Price, J \& Mueller, C 1986, "On the causal ordering of job satisfaction and organisational commitment”, Academy of Management Journal, vol. 29, no. 4, pp. 847-858.

Elkins, S L 2007, "Job satisfaction and work ethic among workers in a Japanese manufacturing company located in the United States." PhD Thesis, The University of Tennessee.

Flynn, G 1994, "Attitude more valued than ability", Personnel Journal, vol. 73, p. 16.

Ivancevich, J, Olelelns, M \& Matterson, M (1997). Organisational Behaviour and Management, Sydney, Irwin.

Khalil, M \& Abu-Saad, I 2009, "Islamic work ethic among Arab college students in Israel”, Cross Cultural Management: an International Journal, vol. 16, no. 4, pp. 333-346.

Kheder, M Z 2001, "Islamic Fundamentals in Software Engineering", Proceedings of the International Conference on Information Systems and Islam, Kuala Lumpur, 5-7 Nov.

Kline, R B 2005, Principles and Practice of Structural Equation Modeling, New York, The Guilford Press.

Kreie, J \& Cronan, T P 2000, "Making ethical decisions: how companies might influence the choices one makes", Communications of the ACM, pp. 66-71.

Kumar, N \& Rose, R C 2010, "Examining the link between Islamic work ethic and innovation capability", Journal of Management Development, vol. 29, no. 1, pp. 79-93.

Lambert, E \& Hogan, N 2009, "The importance of job satisfaction and organisational commitment in shaping turnover intent", Criminal Justice Review, vol. 34, no. 1, pp. 96-118.

Leonard, L N K \& Cronan, T P 2005, “Attitude toward ethical behaviour in computer use: a shifting model”, Industrial Management \& Data Systems, vol. 105, no. 9, pp. 1150-1171.

Markovits, Y, Davis, A J \& van Dick, R 2007, "Organisational commitment profiles and job satisfaction among Greek private and public sector employees", International Journal of Cross Cultural Management, vol. 7, no. 1, pp. 77-99.

Mowday, R T, Steers, R M \& Porter, L W 1979, “The measurement of organisational commitment", Journal of Vocational Behaviour, vol. 14, pp. 224-247.

Muhammad, M Z, Ilias, A, Ghazali, M F, Abdullah, R C \& Amin, H 2008, “An analysis of Islamic ethics in small and medium enterprises (SMEs)", UNITAR E-journal, vol. 4, no. 1, pp. 46-58.

Paradice, D B 1990, "Ethical attitudes of entry-level MIS personnel", Information and Management, vol. 18, pp. 143-151.

Peterson, D K, Puia, G M \& Suess, F R 2003, "Yo Tengo La Camiseta (I have the shirt on): an exploration of job satisfaction and commitment among workers in Mexico", Journal of Leadership \& Organisational Studies, vol. 10, no. 2, pp. 73-88.

Pierce, M A \& Henry, J W, 2000, "Judgements about computer ethics: do individual, co-worker and company judgments differ? Do company codes make a difference?” Journal of Business Ethics, vol. 28, pp. 307-322.

Porter, L W Steers, R M, Mowday, R T, \& Boulian, P V 1974, “Organisational commitment, job satisfaction and turnover among psychiatric technicians", Journal of Applied Psychology, vol. 59, pp. 603-609.

Rahman, N M, Muhamad, N \& Othman, A S 2006, "The relationship between Islamic work ethics and organisational commitment: a case analysis", Malaysian Management Review, vol. 41, no. 1, pp. 79-89.

Raykov, T 2000, A First Course in Structural Equation Modeling, Philadelphia, Lawrence Erlbaum.

Uygur, S 2009, "The Islamic work ethic and the emergence of Turkish SME owner-managers", Journal of Business Ethics, vol. 88, no. 1, pp. 211-225. 
Yousef D A 2000, "Organisational commitment as a mediator of the relationship between Islamic Work Ethic and attitudes toward organisational change", Human Relations, vol. 53, no. 4, pp. 513537.

Yousef D A 2001, "Islamic work ethic: a moderator between organisational commitment and job satisfaction in a cross-cultural context", Personnel Review, vol. 30, no. 2, pp. 152-169.

Yusuf, A A \& Shamsuri, N A 2006, "Organisational justice as a determinant between organisational culture and job satisfaction", Malaysian Management Review, vol. 41, no. 1, pp. 47-62. 


\section{Appendix A Items used in final data analysis}

\begin{tabular}{|c|c|}
\hline Constructs & Items in Questionnaire \\
\hline \multirow[t]{5}{*}{ Islamic work ethic } & Dedication in work is a virtue. \\
\hline & Devotion to quality work is a virtue. \\
\hline & One should carry out work to the best of his ability. \\
\hline & Work is a source of self-respect. \\
\hline & One should take community affairs into consideration in his/her work. \\
\hline \multirow[t]{5}{*}{$\begin{array}{l}\text { Computer use } \\
\text { ethics }\end{array}$} & $\begin{array}{l}\text { The company pays for computer time on a large computer. (measures } \\
\text { responsible use) } \\
\text { Action: An employee plays games on the system. }\end{array}$ \\
\hline & $\begin{array}{l}\text { An employee designed a computer application which was the key to a } \\
\text { discovery made by the Engineering Division of the company. (measures } \\
\text { acknowledgement) } \\
\text { Action: The Engineering Division was given various awards and recognition } \\
\text { with no mention of the program or the programmer. }\end{array}$ \\
\hline & $\begin{array}{l}\text { Many workers who use the computer system in the company do not take the } \\
\text { time to log out properly. (measures disruptive behaviour) } \\
\text { Action: A systems programmer decided to teach the workers a lesson by } \\
\text { locking out those who had violated the log out procedure for } 24 \text { hours with a } \\
\text { message indicating why they were locked out of their accounts. }\end{array}$ \\
\hline & $\begin{array}{l}\text { An employee is considering applying for a new job with another company. } \\
\text { (measures personal non-profit) } \\
\text { Action: The employee returns to the office after work and uses a computer } \\
\text { with a word-processing package to type a resume. }\end{array}$ \\
\hline & $\begin{array}{l}\text { An employee with access to personnel records is going to ask for a raise. } \\
\text { (measures personal profit) } \\
\text { Action: Before meeting with the boss, the employee accesses salary } \\
\text { information of others in similar jobs to document his/her case for the raise. }\end{array}$ \\
\hline \multirow[t]{3}{*}{ Job satisfaction } & Work gives me a sense of accomplishment. \\
\hline & Work is satisfying. \\
\hline & I am doing something worthwhile in my job. \\
\hline \multirow{8}{*}{$\begin{array}{l}\text { Organisational } \\
\text { commitment }\end{array}$} & I am willing to put forth great effort to help this organisation succeed. \\
\hline & I talk to friends about this organisation as a great place to work. \\
\hline & I accept almost any type of job assignment to stay with the organisation. \\
\hline & My values and this organisation's values are similar. \\
\hline & I am proud to tell others that I am part of this organisation. \\
\hline & This organisation inspires me to perform at high levels. \\
\hline & I am glad I chose this organisation over others. \\
\hline & I really care about the fate of this organisation. \\
\hline
\end{tabular}


